\title{
New occurrences of Modulidae (Mollusca: Gastropoda) from European Eocene, Oligocene and Miocene deposits: Data from 19th century collections
}

\author{
Pierre Lozouet ${ }^{1}$ \\ Bruno CaHuzac ${ }^{2}$ \\ Laurent CharLes ${ }^{3}$
}

\begin{abstract}
A re-examination of the historical collections deposited at the Bordeaux Museum of Natural History and the Faculty of Sciences of the University of Bordeaux made it possible to identify new taxa of Modulidae in the Oligocene and Miocene of the Aquitaine Basin. These Modulidae belong to the American groups Modulus modulus and Trochomodulus. In addition, three new species are described: Modulus benoisti sp. nov. (Serravallian), Trochomodulus stampinicus sp. nov. (Rupelian), which is close to Trochomodulus sublaevigatus (ORBIGNY, 1852), a Chattian species, and Incisilabium trochiformis sp. nov. (Priabonian). The latter is the oldest known Modulidae, together with Incisilabium parisiensis (DESHAYES, 1832) (Middle Eocene) that was previously classified in the Trochidae. These results show that the paleobiogeography and origin of the family Modulidae need to be reconsidered.
\end{abstract}

Key-words:

- Aquitaine Basin;

- Cenozoic;

- paleobiogeography;

- Gastropoda;

- new species

Citation: Lozouet P., CAhuzac B. \& Charles L. (2020).- New occurrences of Modulidae (Mollusca: Gastropoda) from European Eocene, Oligocene and Miocene deposits: Data from $19^{\text {th }}$ century collections.- Carnets Geol., Madrid, vol. 20, no. 7, p. 125-139.

Résumé : Nouvelles occurrences de Modulidae (Mollusca : Gastropoda) dans des gisements européens de l'Éocène, de I'Oligocène et du Miocène : Données de collections du $19^{\circledR}$ siècle.L'examen de collections historiques déposées au Muséum d'Histoire Naturelle de Bordeaux et à la Faculté des Sciences de l'Université de Bordeaux a permis d'identifier de nouveaux taxons de Modulidae dans l'Oligocène et le Miocène du bassin aquitain. Ces Modulidae appartiennent aux groupes américains Modulus modulus et Trochomodulus. Trois nouvelles espèces sont décrites : Modulus benoisti nov. sp. (Serravallien), Trochomodulus stampinicus nov. sp. (Rupélien), proche de Trochomodulus sublaevigatus (ORBIGNY, 1852), une espèce chattienne, et Incisilabium trochiformis nov. sp. (Priabonien). Ce dernier est le plus ancien Modulidae connu avec Incisilabium parisiensis (DESHAYES, 1832) (Éocène moyen) précédemment classé dans les Trochidae. Ces résultats montrent que la paléobiogéographie et l'origine de la famille des Modulidae doivent être réexaminées.

Mots-clefs :

- Bassin d'Aquitaine ;

- Cénozoïque ;

- paléobiogéographie ;

- Gastropoda ;

- nouvelles espèces

\footnotetext{
${ }^{1}$ Muséum national d'Histoire naturelle, Direction des Collections, CP 51, 55 rue de Buffon, 75231 Paris Cedex 05 (France)

lozouet@mnhn.fr

2 Université de Bordeaux, 351 Cours de la Libération, F - 33405 Talence Cedex (France)

bruno.cahuzac@u-bordeaux.fr

${ }^{3}$ Muséum de Bordeaux - sciences et nature, 5 Place Bardineau, F - 33000 Bordeaux (France)

l.charles@mairie-bordeaux.fr
}

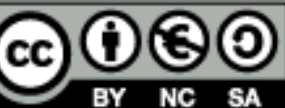

Published online in final form (pdf) on March 17, 2020

[Editor: Bruno GRANIER; language editor: Simon MITCHELL] 


\section{Introduction}

The Modulidae is a littoral cerithioid family which occurs throughout the tropical and subtropical regions. It is relatively rare in fossil deposits. It is also a paucispecific family with about 12-16 living species. The tropical American regions are relatively rich with at least eleven living species, whereas there are two or three species in the eastern Pacific and nine or more species in the western Atlantic, and an equivalent number or more of fossil species (LANDAU et al., 2014). In comparison, only two species are recognised in the vast West Indo-Pacific region (LOzOUET \& KRYGELMANS, 2016; BouCHET, 2018), and only one species is known from European Miocene deposits.
This paper reports the rediscovery of Modulidae in the Oligocene and Miocene of the Aquitaine Basin, belonging to genera that were previously thought to be exclusively Caribbean (Modulus and Trochomodulus), in three historical collections (MHNBX: coll. BENOIST; UB: general collection and coll. Grateloup). It also describes a new species of Incisilabium from the Upper Eocene.

Abbreviations used: Length, SL; Last whorl Length, SWL; Diameter, SD (Shell measurements); MNHN-IM, Muséum national d'Histoire naturelle (French National Museum of Natural History), Malacology; MNHN.F, Muséum national d'Histoire naturelle, Paleontology; MHNBx, Muséum d'Histoire naturelle de Bordeaux (Bordeaux Museum of Natural History); UB, Université de Bordeaux (University of Bordeaux), no. TYFIPAL ["TYpes et FIgurés en PALéontologie" (TYpe and FIgured specimens in PALeontology)].

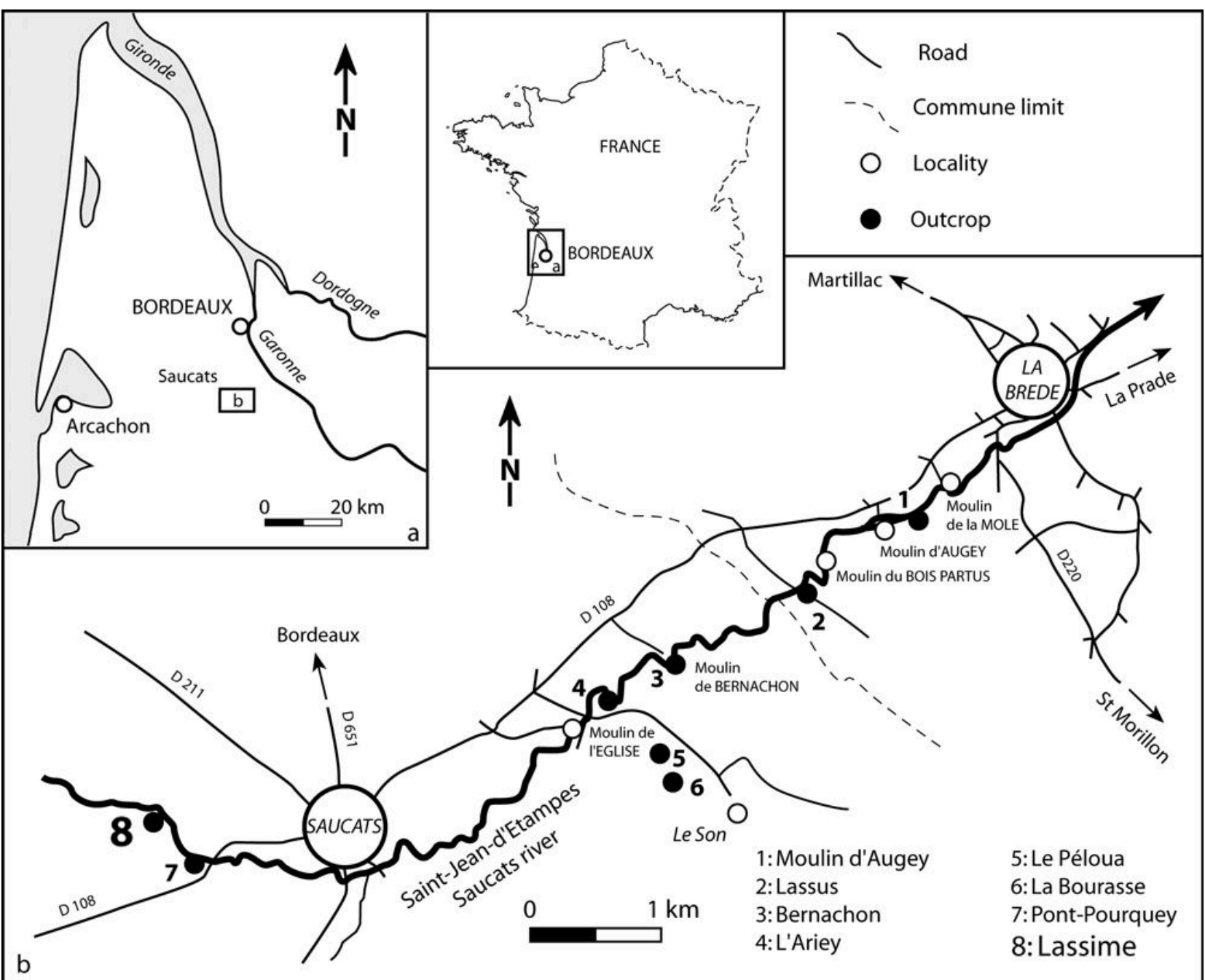

Figure 1: Location map of the Miocene of Saucats area, exposed between La Brède (downstream) and Saucats (upstream) villages. Succession of the stratotypic outcrops of the Aquitanian: 1 to 4; Burdigalian: 5 to 7; Serravallian : 8 (Lassime section). 


\section{Geological framework and BENOIST's historical collections}

Along the "St-Jean-d'Étampes" stream (Gironde, Saucats and La Brède), geological strata from the Lower to Middle Miocene are exposed (Fig. 1 ). These include the classic outcrops of the Aquitanian stratotype and outcrops of the Burdigalian stratotype. This territory is partially protected and constitutes since 1982 the "Réserve Naturelle Géologique de Saucats-La Brède" (Natural Geological Reserve of Saucats-La Brède, RNG), which was the first geological Reserve created in France. Most of the exposed strata belong to the Lower Miocene (Aquitanian and Burdigalian) but a limited part of the section, at the site named "La Sime, Cazenave" (now called Lassime), contains layers belonging to the marine Middle Miocene (Serravallian) (MAYER, 1858; LINDER, 1872). The Serravallian deposits overlie the uppermost levels of the local Burdigalian (Fig. 2). This section shows therefore that a regional stratigraphical gap exists corresponding to a hiatus including the Upper Burdigalian, the Langhian and the Lower Serravallian stages (LONDEIX \& JAN DU CHÊNE, 1998; PARIze et al., 2008).

The macrofauna from this deposit, and in particular the malacofauna, was listed long ago by BENOIST $(1873,1874)$ who identified 230 species. BENOIST (1845-1904), a dentist by profession, is one of the main contributors to current knowledge of fossil molluscs from the Saucats Valley. His collection was donated to, and has been partly preserved in, the Muséum de Bordeaux since 1900.

Excavation of a new outcrop at the Lassime site (on the right bank of the stream) was carried out by the RNG. In the Serravallian stage, three units have been distinguished. The Middle Miocene sequence begins with a transgressive conglomerate containing calcareous pebbles. Dating using strontium isotopes on Glycymeris shells ( $\mathrm{Bi}$ valvia) provided an age of $12.9 \pm 0.7 \mathrm{Ma}$ for this basal layer (Fig. 2, level B, CAHUZAC et al., 1997). Using non-reworked glauconite grains from the top of the outcrop, the K-Ar method gave an estimated age of $11.6 \pm 0.2 \mathrm{Ma}$ (Fig. 1, level D). Unfortunately, the molluscs are poorly preserved in this outcrop, except for very thick shells and large bivalves with a calcitic shell (Pectinidae). Nevertheless, the collections have allowed us to complete our knowledge of the Pectinidae and to list 10 species (CAHUZAC, 2005).

Cossmann and PeYrot (1909-1924) and PeYrot (1925-1935) listed 135 species from the Serravallian of Lassime. Among them, there are 25 type and figured specimens. However, CosSMANN and PEYROT indicate for 71 species "fide BENOIST", which clearly means that they did not personally see most of the species. CAHUzAC and CluzAUD (1999a, 1999b) found only 15 species in the old collections. For these authors, a doubt exists about the presence of many species at Lassime. The question is whether BENOIST's lists $(1873,1874)$ can be trusted to indicate the richness of Lassime's fauna or are untrustworthy. According to BENOIST, the fauna of Lassime is original, distinct from that of the equivalent levels known in Aquitaine (the so-called "Sallomacian" of Gironde [at Salles]; the "Helvetian" of Pyrénées-Atlantiques [at Orthez]). This raises many questions. One of them concerns BENOIST's citation (1874: p. 287) of the occurrence of the Recent species "Modulus lenticularis (= Modulus modulus)" represented by two specimens in his collection (our PI. 1, figs. 18 ). No other specimen of Modulus was known from the Serravallian of the Aquitaine Basin and the Modulus modulus species-group was considered to be exclusively American. However, the specimens in BENOIST's collection from "Lassime" are really very close to the Modulus modulus of the Caribbean (see PI. 1, figs. 9-12). Because BENOIST has also acquired a certain (perhaps unjustified) reputation as a forger, at least in the domain of Archaeology (GENDRY, 2015), the first author (P. LOZOUET) had a long-standing hesitation before considering that these Modulus really came from the Serravallian of Aquitaine.

Today, consultation of another historical collection from Lassime (made in the 19th century) preserved at the University of Bordeaux (UB) finally clears all ambiguity because among the few lots of preserved molluscs, there is a specimen of Modulus identical to those from the BENOIST collection. Therefore, we confirm that the Modulus modulus species-group is really present in the Middle Miocene of Aquitaine. Although we cannot affirm that BENOIST's lists are correct, this find leads credence to the fact that some of the records are correct. Moreover, the molluscs in the UB collection show some embedded dark grey sandy marl sediment, comparable to LINDER's (1872: p. 472) description of an outcrop on the left bank of the river (below Cazenave farm, upstream from Lassime) which supplied numerous small gastropods. In this outcrop the molluscs were clearly better preserved than those in the classic section currently still visible on the right bank of the river.

\section{Modulidae in the GrATELOUP collection}

From 1827 to 1847 , the physician Jean-Pierre Sylvestre GRATELOUP (1782-1861) described several hundred species of gastropods from the Oligocene and Miocene epochs of the Aquitaine basin and particularly from the Adour Basin. A large part of his collection of new species was illustrated by Grateloup in his famous "Atlas Conchyliologique" and in other papers. However, his drawings are in some cases excessively caricatured and the descriptions very minimal or absent. This hampers recognition of the species. In addition, the GRATELOUP collection has been subjected to many tribulations and moves over time. One of the two pieces of furniture housing the collection 


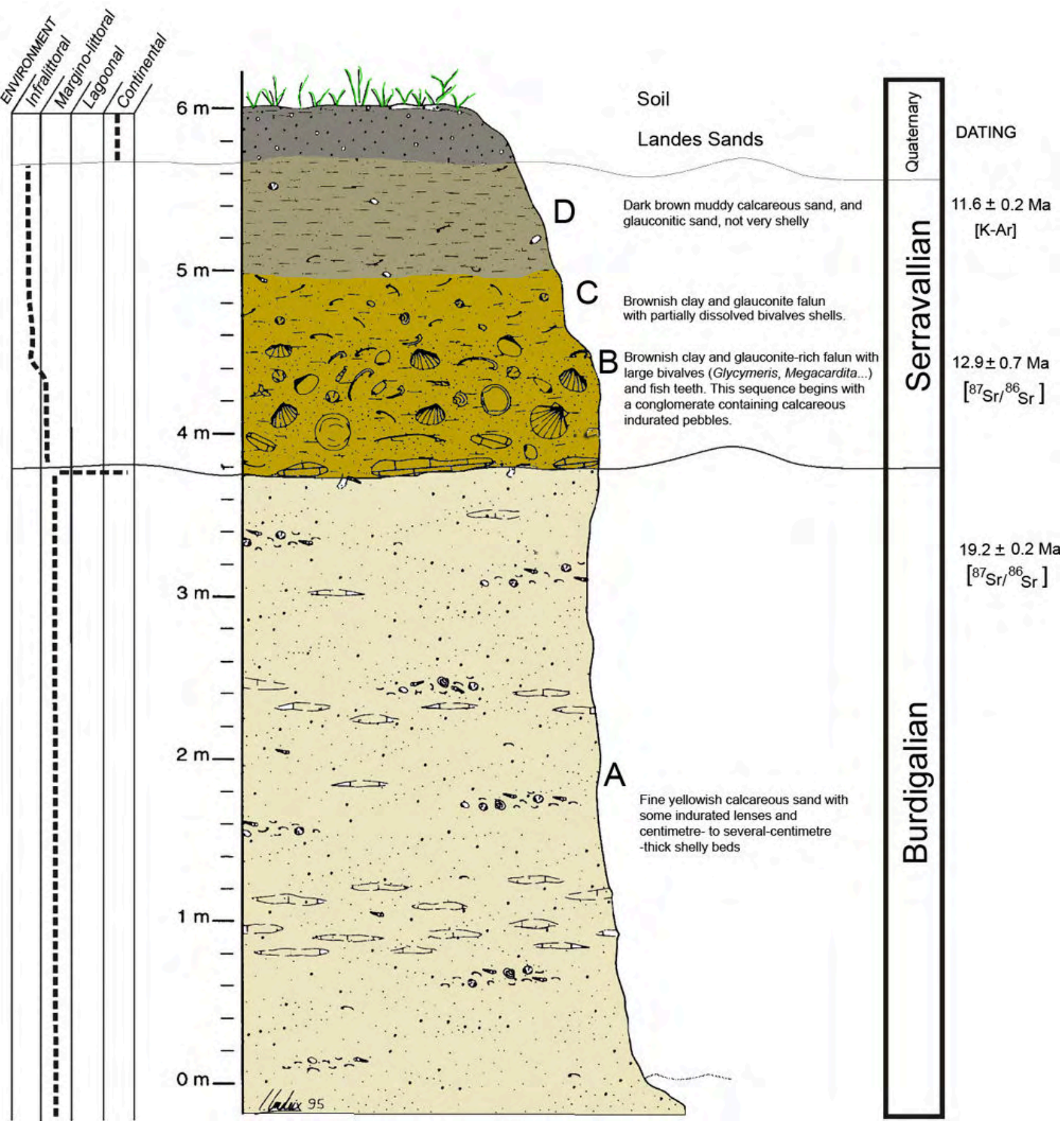

Figure 2: The section from Lassime. Dating was by strontium isotopes $\left[{ }^{87} \mathrm{Sr} /{ }^{86} \mathrm{Sr}\right.$ ] (CAHUZAC et al., 1997) in shells and K-Ar dating of non-reworked glauconite-grains (level D) (PARIZE et al., 2008). Modified from LoNDEIX and JAN DU CHÊNE (1998).

historically, had a transport accident with many drawers capsizing, resulting in mixing of shells. As a result, many specimens are found without their respective labels. Consequently, personal interpretation is necessary when reclassifying and revising the collection (CAHUZAC et al., 2004). The collection is currently housed at the Faculty of Sciences of the University of Bordeaux.

Our preliminary work of arranging the Trochoidea of the GRATELOUP collection led us to select a problematic specimen illustrated by GRATELOUP (1845, Pl. 13, fig. 16). GRATELOUP (1832) named this specimen Trochus laevigatus, unfortunately a junior homonym of Trochus laevigatus GMELIN, 1791, and SOWERBY, 1817. Consequently, OrBIGNY
(1852) introduced the name Trochus sublaevigatus with a reference to [PI. 1, no. 13, fig. 16] in GRATELOUP (1845). GRATELOup's drawing is not very faithful and the spire of the shell has been restored (Fig. 3). However, the recovered specimen appears to be similar in shape and size to GRATELOUP's figure.

Our observation shows that Trochus sublaevigatus is not a Trochidae or Trochoidea but a member of the Modulidae, as indicated by the lack of nacreous structure and the characteristic columella ending with a columellar tooth. In fact, the trochoidal shape and the deeply lirate aperture within make it possible to classify this species within the American genus Trochomodulus. 


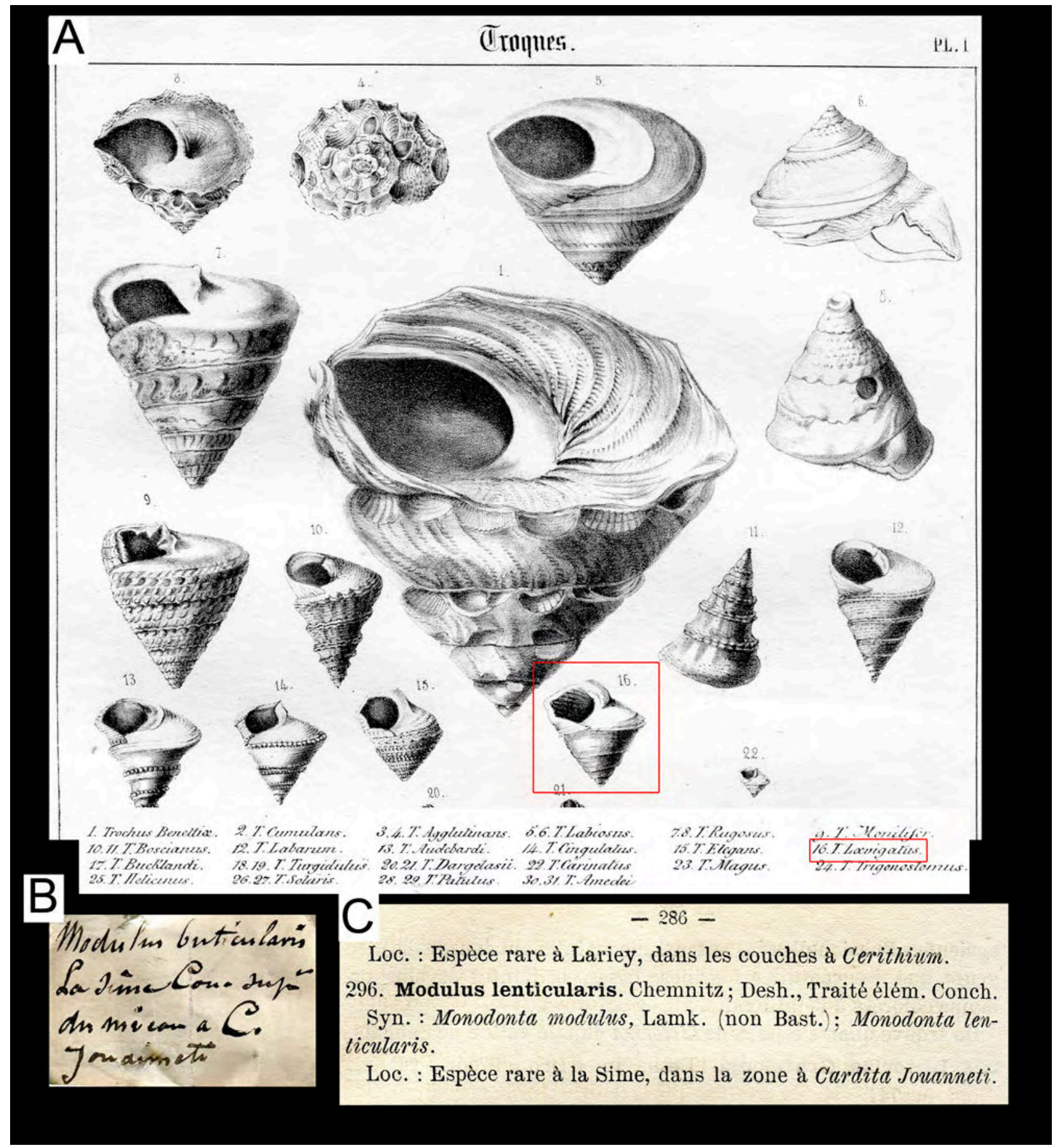

Figure 3: Graphic assemblage of historical data. A, montage of the plate by Grateloup, 1845 (PI. 1, no. 13) including Trochus laevigatus (Fig. 16). B, label (BENOIST's handwriting) indicating Modulus lenticularis from the "La Sime" layer with the bivalvia Cardita jouanneti (verbatim: "Couche supérieure du niveau à C. jouanneti"). C, The same data is reported in BENOIST (1874, p. 286) translation: uncommon species in La Sime, from the "Cardita Jouanneti" zone.

\section{Eocene and Lower Oligocene Modulidae}

Our further examination of recently collected material from the Aquitaine basin revealed the occurrence of new Lower Oligocene and Upper Eocene species. The Lower Oligocene species is the oldest occurrence of the genus Trochomodulus. The Priabonian species, classified in the genus Incisilabium, is one of the oldest species reported in the Modulidae. We describe these species below.

\section{Systematic description}

\section{Family Modulidae P. FISCHER, 1884}

The classification of the Modulidae is based for the present time on the general morphology of the shell. The aperture, and in particular the siphonal area (LANDAU et al., 2014; see also LoZOUET \& KRYGELMANS, 2016, Fig. 2), are regarded as the main diagnostic features. The genera Modulus and Trochomodulus share the same reinforced siphonal depression which is well delimited 
by a siphonal ridge. In the Modulus modulus group, the siphonal depression is particularly well developed and spoon-shaped. LANDAU et al. (2014) divide the family Modulidae into six genera. Among them, Laevimodulus and Psammodulus are exclusively fossil tropical American genera, with records in the Miocene-Pliocene. Trochomodulus was up to now also considered as exclusively a tropical American genus represented from the late early Miocene to the present-day, in the Caribbean and Panama. New data revealed here show that the group is also present in European Oligocene deposits.

\section{Modulus GrAY, 1842}

Type species: Trochus modulus LinNaEUs, 1758 (by subsequent monotypy). Locality/age: Caribbean, Recent.

\section{Modulus benoisti sp. nov.}

PI. 1, figs. 1-8, 13-18

1874 Modulus lenticularis Chemnitz - BENOIST: 10, no. 296: 286.

Type material. Holotype [MHNBx 2014.14. 37.1]; paratype 1 [MHNBx 2014.14.37.2], paratype 2 [UB 84-2-13].

Type locality. France, Aquitaine Basin, Saucats "Lassime".

Age. Middle Miocene (Serravallian).

Etymology. Dedicated to É.-A. BENOIST who identified this species for the first time and collected two precious specimens.

Dimensions. Holotype: $\mathrm{SL}=8.5 \mathrm{~mm}, \mathrm{SD}=$ $10.8 \mathrm{~mm}, \mathrm{SWL}=7.2 \mathrm{~mm}$; Paratype 1: $\mathrm{SL}=7$ $\mathrm{mm}, \mathrm{SD}=8 \mathrm{~mm}, \mathrm{SWL}=6.3 \mathrm{~mm}$; Paratype 2: SL $=17 \mathrm{~mm}, \mathrm{SD}=18 \mathrm{~mm}, \mathrm{SWL}=9 \mathrm{~mm}$.

Description. Shell of medium size, solid, angular, turbiniform with a large pyramidal shape and a depressed spire. Protoconch unknown. Teleoconch of more than 3.5 whorls separated by a suture, deeply impressed and undulating. Sculpture on the spire with 4 spiral cords, three fine and one very large above the sutural line; eleven axial obsolete ribs, irregular, undulating, poorly delineated. Entire shell covered by numerous and fine growth lines.

Body whorl occupies $85 \%$ of total length of shell. Sutural ramp wide, rounded, shoulder angular. Sculpture of sutural ramp consisting of 1011 axial obsolete ribs stopping at the periphery and 5 primary cords with 1 secondary cord in the interspaces; then a very strong primary cord delimiting the ramp; sculpture of the base consisting of 5-6 primary cords and 2-3 secondary cords on the neck. Umbilicus small, but deep. Large subquadrate aperture with a fine callus on parietal part; siphonal canal with siphonal notch and a reinforced, spoon-shaped siphonal depression; anal canal not developed. Columella deeply excavated in mid-portion, with developed callus and a strong, abapical columellar tooth. Outer lip, sharp, prosocline, deeply lirate inside, by seven lirae.
Discussion. The similarity of Modulus benoisti and Modulus modulus is striking (PI. 1). We compared the former with subfossil specimens of Modulus modulus (PI. 1, figs. 9-12) collected off Martinique island during the Madibenthos Expedition (Martinique, Gros Îlet, Stn AD618 1m, 14 $\left.32.9^{\prime} \mathrm{N}-61^{\circ} 01.3^{\prime} \mathrm{W}\right)$. Modulus modulus exhibits a large variation (see LAMY \& POINTIER, 2017, PI. 39, fig. 3a-f) and LANDAU et al. (2014, Figs. 2-8) suspected a species complex. The only significant difference between the Aquitaine and Caribbean species appears to be the stronger spiral cords in Caribbean shells. The common European Early Miocene species Modulus basteroti BENOIST, 1874 (PI. 3, figs. 1-4) exhibits a form with a higher spire and lacks the reinforced spoon-shaped siphonal depression observed in the Modulus modulus species-group. In fact, the generic placement of M. basteroti is questionable (LOZOUET \& KRYGELMANS, 2016) and cannot be resolved without reconsidering the classification of the family, but it seems to not belong to the Modulus modulus species-group. Modulus basteroti is cited from the Middle Miocene of the Paratethys and Italy. SAcco (1896, PI. 1, figs. 2-4) described two varieties of M. basteroti from the "Colli Torinesi". Both have a higher spire and more prominent axial ribs than M. benoisti.

Trochomodulus LANDAU, VermeiJ \& ReICH, 2014

Type species: Modulus catenulatus PHILIPPI, 1849 (by original designation). Locality/age: East Pacific, Recent.

\section{Trochomodulus stampinicus sp. nov.}

$$
\text { PI. 2, figs. 11-19 }
$$

Type material. Holotype [MNHN.F.A.71174]; 2 paratypes [MNHN.F.A.71172-73].

Type locality. France, Aquitaine Basin, Gaas "Lagouarde".

Age. Lower Oligocene (Rupelian).

Etymology. Species only known from the Lower Oligocene (Stampian = Rupelian).

Dimensions. Holotype: $\mathrm{SL}=15.5 \mathrm{~mm}, \mathrm{SD}=$ $15 \mathrm{~mm}, \mathrm{SWL}=12 \mathrm{~mm}$; Paratype 1: $\mathrm{SL}=2.4 \mathrm{~mm}$, $\mathrm{SD}=2.3 \mathrm{~mm}, \mathrm{SWL}=1.8 \mathrm{~mm}$ (Landes, Orist).

Other material examined. 4 specimens, Landes, Orist.

Description (holotype). Shell of medium size, almost as high as it is wide, solid, trochiform with a pyramidal shape. Protoconch unknown. Teleoconch of more than 5 weakly concave whorls separated by an impressed suture. Sculpture on spire with 4-6 primary granular spiral cords, abapical cord stronger. Entire shell covered by numerous fine growth lines. Body whorl occupies $77 \%$ of total length of shell, angular at the periphery; sculpture consisting of 7 primary granular cords with a strong keel-like peripheral cord and 1 secondary cord in the interspaces; sculpture on base consisting of 6 cords. Umbilicus almost closed. Large subquadrate aperture with a fine callus on parietal part; siphonal canal with si- 
phonal notch, anal canal and siphonal depression not developed. Columella excavated in mid-portion, with a blunt columellar tooth, callus not developed but probably worn. Outer lip sharp, prosocline, deeply lirate inside by seven lirae.

Remark. Paratype 1 (young specimen) with 4 spiral cords on the penultimate whorl. Adapical cord with very large granules. Adapical cord and abapical cord are larger. Abapical cord on last whorl almost smooth, forming a strong keel delimiting the base.

Discussion. Trochomodulus stampinicus is easily separated from $T$. sublaevigatus by its granular cords. The same observation applies for American species, none of which have such granular spiral cords (LANDAU et al., 2014).

\section{Trochomodulus sublaevigatus (ORBIGNY, 1852)}

PI. 2, figs. 1-10

1832 Trochus laevigatus Grateloup: no. 201, 143 (non SOWERBY, 1817).

1845 Trochus laevigatus GratelouP - GratelouP: PI. 1 (no. 13), fig. 16.

1852 Trochus sublaevigatus d'ORBIGNY: no. 642, 42.

Material examined. Upper Oligocene, Chattian: lectotype designated here $(\mathrm{SL}=16.2 \mathrm{~mm}$, $\mathrm{SD}=13 \mathrm{~mm}$ ) (PI. 2, figs. 4-6), coll. GRATELOUP [UB-65-2-141] specimen of GRATELOUP (1845, PI. 13, fig. 16), Landes, St-Paul-lès-Dax "faluns jaunes". Landes, St-Paul-lès-Dax ["Abesse, Château" 1 specimen (PI. 2, figs. 7-10), MNHN.F.A.71171; Lestrilles 5 specimens, PI. 2, figs. 1-3, MNHN.F.A. 71170].

Discussion. Trochomodulus paraguanensis LANDAU et al., 2014, from the Lower Miocene (Burdigalian) of Venezuela is similar in shape to T. sublaevigatus; however, the spiral cords are less numerous and sharper in $T$. paraguanensis (see LANDAU et al., 2014, Figs. 54-58).

\section{Incisilabium CossmanN, 1918}

Type species: Monodonta parisiensis DeSHAYES, 1832 (by original designation). Locality/age: Paris Basin, Middle Eocene, Bartonian.

\section{Incisilabium trochiformis sp. nov.}

$$
\text { PI. 3, figs. 10-16 }
$$

Type material. Holotype [MNHN.F.A.71175]; 3 paratypes [MNHN.F.A.71176-77-78].

Type locality. France, Aquitaine Basin, Peyrehorade "Lasserre".

Age. Upper Eocene (Priabonian).

Etymology. From the shape of the shell.

Dimensions. Holotype: $\mathrm{SL}=5.1 \mathrm{~mm}, \mathrm{SD}=$ $4.2 \mathrm{~mm}, \mathrm{SWL}=12 \mathrm{~mm}$; Paratype 1: $\mathrm{SL}=4.4$ $\mathrm{mm}, \mathrm{SD}=4.5 \mathrm{~mm}$; Paratype 2: $\mathrm{SL}=3.7 \mathrm{~mm}$, $\mathrm{SD}=3.7 \mathrm{~mm}$; Paratype 3: juvenile specimen.

Other material examined. 23 young specimens, Landes, Peyrehorade "Lasserre".

Description (holotype). Shell of small size, almost as high as it is wide, solid, trochiform with a pyramidal shape. Protoconch of planktotrophic larval type, of 2.5 convex whorls, with a small nucleus, well demarcated from the teleoconch; Protoconch I smooth, Protoconch II with spiral threads and axial riblets. Teleoconch (worn) of 45 whorls, separated by a fine impressed suture. Spire weakly concave with 4-6 primary spiral cords, abapical cord stronger. Body whorl occupies $82 \%$ of the total length of the shell, sutural ramp wide weakly concave, shoulder angular. Sutural ramp wide, delimited by a strong cord (shoulder angle) and sculptured with 6-7 cords, adapical cord (along the suture) strong. Median part of the whorl (between the base and the sutural ramp) with 3 cords; base rounded, circumscribed by a strong cord, bearing $11-12$ primary cords; in total 22-24 spiral cords on the body whorl. Umbilicus closed. Large aperture, subquadrate, with a fine callus on the parietal part; siphonal canal with weak siphonal notch; anal canal and siphonal depression not developed. Columella excavated in mid-portion, with a blunt columellar tooth. Outer lip with a bevelled edge, prosocline, smooth inside of aperture.

Discussion. Incisilabium trochiformis is separated from $I$. parisiensis (PI. 3, figs. 5-9) by its non-granular spiral cords. It differs from Trochomodulus by the weakness of its siphonal notch and columellar tooth as well as its smooth inside outer lip.

\section{Conclusions}

The European Middle Miocene Modulus benoisti n. sp., which belongs to the Caribbean Modulus modulus species-group, is a striking example of a fossil species which is difficult to distinguish from a Recent species that is geographically and stratigraphically distant. Until now, Trochomodulus was considered to be an exclusively tropical American genus, ranging from the late early Miocene to the present in the tropical Caribbean and Pacific provinces (LANDAU et al., 2014). Its presence in Europe since at least the Lower Oligocene was unexpected. In fact, Modulus benoisti, Trochomodulus stampinicus and Trochomodulus sublaevigatus point to trans-Atlantic interchanges of taxa during the Oligocene and the Neogene but also to a bias in the fossil record. Fossil Modulidae are relatively rare in the Cenozoic and can be easily confused with the Trochoidea, as exemplified by misinterpretation of Trochus sublaevigatus. Accordingly, the oldest unambiguous member of the Modulidae was reported from the Middle Eocene of Europe with the genus Incisilabium COSSMANN, 1918 (LOZOUET \& KRYgeLmans, 2016, Fig. 2F; Cossmann \& PissarRo, 1907, PI. 3, fig. 22-1) formerly classified in the Trochidae. It is the reason why LANDAU et al. (2014) have neglected this reference and considered that the oldest known Modulidae came from the American Upper Eocene/Lower Oligocene. The statement by these authors that "the fossil record strongly indicates a tropical American origin for the Modulidae" therefore is no longer valid. 
Molecular phylogeny by STRONG et al. (2011) shows that the Modulidae/Scaliolidae are very close to the Potamididae and places them at the base of a clade uniting the fresh-water Paludomidae and Thiaridae. This phylogeny implies a very early divergence for the Modulidae. Finally, this new data further confirms that the paleobiogeographical history of the Modulidae is more complex than expected and the origin of the family is probably older than the Eocene epoch. We may therefore expect the discovery of earlier species of Modulidae in the future.

\section{Acknowledgments}

We would like to thank Philippe Rocher (RNG Saucats-La Brède) Laurent LoNDEIX (UB, Bordeaux) who provided information on the RNG, and Jean-Michel PACAUD (MNHN-Paris) for the loan of material. Thank you to Geerat VerMeIJ (Davis, USA) and Jean-Claude PLAZIAT (Paris) for comments. Thank you also to Claudia RATTI (MNHN, Paris) for polishing the English of the manuscript.

\section{Bibliographic references}

BENOIST É.-A. (1873).- Catalogue synonymique et raisonné des testacés fossiles recueillis dans les faluns miocènes des communes de La Brède et de Saucats.- Actes de la Société Linnéenne de Bordeaux, tome 29, p. 5-78.

BENOIST É.-A. (1874).- Catalogue synonymique et raisonné des testacés fossiles recueillis dans les faluns miocènes des communes de La Brède et de Saucats.- Actes de la Société Linnéenne de Bordeaux, tome 29, p. 265-460.

BOUCHET P. (2018).- MolluscaBase. Indomodulus LANDAU, VermeIJ \& ReICH, 2014. URL: http:// www. molluscabase.org/aphia.php? $p=$ taxdetail s\&id=817008 [last accessed on 2018-10-04] .

CAHUZAC B. (2005).- Découverte de Pecten praebenedictus (Bivalvia, Pectinidae) dans le Serravallien de Saucats (SW France); aperçu sur les Pectinidae de ce site.- Bulletin de la Société Linnéenne de Bordeaux (nouv. série), tome 140 , no. 33 (1), p. 21-42.

CAHUZAC B. \& Cluzaud A. (1999a).- Bilan scientifique et synthèse des données bibliographiques sur le Miocène moyen (Serravallien) de Saucats (Gironde, Bassin d'Aquitaine).- Bulletin de la Société Linnéenne de Bordeaux, vol. 27, no. 2, p. 95-111.

Cahuzac B. \& Cluzaud A. (1999b).- Bilan scientifique et synthèse des données bibliographiques sur le Miocène moyen (Serravallien) de Saucats (Gironde, Bassin d'Aquitaine). (suite et fin).- Bulletin de la Société Linnéenne de Bordeaux, vol. 27, no. 3, p. 113-133.

CAHUzac B., TURPin L. \& Bonhomme B. (1997).- Sr isotope record in the area of the Lower Miocene historical stratotypes of the Aquitaine Basin (France). In: Montanari A., Odin G.S. \& CocCIONI R. (eds.), Miocene Stratigraphy - an integrated approach.- Developments in Palaeonto- logy and Stratigraphy, vol. 15, chapter A 4, p. 33-56.

Cahuzac B., Lesport J.-F. \& Lagarde L. (2004).Révision des Cancellariidae (Mollusca, Gastropoda) décrites par GRATELOUP (1827-1847) dans le Miocène des Landes (SW France).Geodiversitas, Paris, vol. 26, no. 2, p. 207261.

Cossmann M. \& Peyrot A. (1909-1924).- Conchologie néogénique de l'Aquitaine.- Actes de la Société Linnéenne de Bordeaux, vol. LXIII (2), 1909 , p. 72-144 (Pls. I-IV); vol. LXIII (3), 1909 , p. $145-232$ (Pls. V-VII); vol. LXIII (4), 1909 , p. 233-293; t. LXIV (4), 1910, p. 235288; t. LXIV (5), 1910, p. 289-400; t. LXIV (6), 1911, p. 401-445 (Pls. VIII-XVIII); t. LXV (2), 1911, p. 51-98; t. LXV (3), 1912, p. 99178 ; t. LXV (4), 1912, p. 179-333 (Pls. XIXXXVIII); t. LXVI (2), 1912, p. 121-168; t. LXVI (3), 1912, p. 169-232; t. LXVI (4), 1913, p. 233-324 (PIs. I-X); t. LXVIII (1), 1914, p. 5-96; t. LXVIII (2), 1914, p. 97-210 (PIs. XIXXII); t. LXVIII (3), 1914, p. 361-435 (Pls. XXIII-XXVI); t. LXIX (3), 1917, p. 158-284; t. LXIX (4), 1917, p. 285-365; t. LXX (1), 1918, p. 5-100; t. LXX (2), 1918, p. 101-180 (Pls. I$X)$; t. LXX (3), 1919, p. 181-356; t. LXX (4), 1919 , p. 357-491 (Pls. XI-XVII); t. LXXIII, 1922 , p. 5-321 (Pls. I-VII); t. LXXIV (3), 1923, p. 257-342; t. LXXV (2), 1924, p. 71144 ; t. LXXV (3), 1924, p. 193-318 (Pls. IVII).

CoSSMANN M. \& PISSARRO G. (1907).- Iconographie complète des coquilles fossiles de l'Éocène des environs de Paris.- Hermann, Paris, Tome II, pars - In-40, Pls. I-IX. URL: https://www. biodiversitylibrary.org/bibliography/52315 - /

GENDRY D. (2015).- Deux paléontologues berrichons: André Émile BENOIST (1845-1904) et l'abbé Alexis Delaunay (1867-1946), et leur contribution à l'étude du Bathonien de SaintGaultier (Indre, France).- Symbioses (nouvelle série), vol. 33, p. 1-16.

Grateloup J.-P.S. (1832).- Tableau (suite du) des coquilles fossiles qu'on rencontre dans les terrains calcaires tertiaires (faluns) des environs de Dax, dans le département des Landes.4ème article.- Actes de la Société Linnéenne de Bordeaux, tome 5(3), no. 27, p. 132-171.

Grateloup J.-P.S. (1845).- Conchyliologie fossile des terrains tertiaires du Bassin de l'Adour (environs de Dax). 1, Univalves. Atlas.- Lafargue, Bordeaux, 45 planches et leurs textes explicatifs $(1,3,5-10,12-48)$.

LAMY D. \& POINTIER J.-P. (2017).- Marine and freshwater molluscs of the French Caribbean.PLB Editions, Gosier, vol. 1, 388 p.

Landau B., VermeiJ G.J. \& Reich S. (2014).- Classification of the Modulidae (Caenogastropoda, Cerithioidea), with new genera and new fossil species from the Neogene of tropical America and Indonesia.- Basteria, Bilthoven, vol. 78, no. 1-3, p. 1-29. 
LINDER O. (1872).- Des dépôts lacustres du vallon de Saucats.- Actes de la Société Linnéenne de Bordeaux ( $3^{\text {ème }}$ série), vol. 27 (1870-1872), p. 451-525.

LONDEIX L. \& JAN DU CHÊNE R. (1998).- Burdigalian dinocyst stratigraphy of the stratotypic area (Bordeaux, France).- Geobios, Villeurbanne, vol. 30, no. 2, p. 283-294.

Lozouet P. \& KRYgelmans A. (2016).- A new species of Indo-Pacific Modulidae (Mollusca: Caenogastropoda).- Zootaxa, Auckland, no. 4103 (2), p. 195-200.

MAYER K. (1858).- Versuch einer neuen Klassifikation der Tertiär-Gebilde Europa's.- Verhandlungen der allgemeinen Schweizerischen Gesellschaft für die gesammten Naturwissenschaften, Basel, p. 70-71, 165-199.

OrBigny A. d' (1852).- Prodrome de paléontologie stratigraphique universelle des animaux mollusques et rayonnés.- vol. 3, $191 \mathrm{p}$.

Parize O., Mulder T., Cahuzac C., Fiet N., Londeix L. \& RuBino J.-L. (2008).- Sedimentology and sequence stratigraphy of Aquitanian and Bur- digalian stratotypes in the Bordeaux area (southwestern France).- C.R. Geoscience, Paris, vol. 340, p. 390-399.

Peyrot A. (1925-1935).- Conchologie néogénique de I'Aquitaine.- Actes de la Société Linnéenne de Bordeaux, t. LXXVII (2), 1925, p. 51-194; t. LXXVIII, 1927, p. 199-256 (Pls. I-IV); t. LXXIX suppl., 1928, p. 5-264 (Pls. V-XIV); t. LXXXII (2), 1931, p. 73-126; t. LXXXIII, 1931, p. 5-116 (PIs. I-X); t. LXXXIV (1), 1932, p. $5-128$; t. LXXXIV (2), 1933, p. 129-288 (Pls. XI-XVIII); t. LXXXV (1), 1933, p. 5-71; t. LXXXVI (2), 1935, p. 257-352.

SAcco F. (1896).- I molluschi dei terreni terziarii del Piemonte e della Liguria. Parte 21.- Carlo Clausen, Torino, 60 p. (4 Pls.).

Strong E.E., Colgan D.J., Healy J.M., lydeard C., Ponder W.F. \& Glaubrecht M. (2011).- Phylogeny of the gastropod superfamily Cerithioidea using morphology and molecules.- Zoological Journal of the Linnean Society, London, vol. 162 , p. 43-89. 


\section{Plates}

Plate 1: 1-8, 13-18. Modulus benoisti sp. nov., Middle Miocene (Serravallian), Gironde, Saucats (Lassime). 1-4, 17: holotype, $\mathrm{SL}=8.5 \mathrm{~mm}$, coll. BENOIST [MHNBx 2014.14.37.1]; 5-8, 18: paratype $1, \mathrm{SL}=7 \mathrm{~mm}$, coll. BENOIST [MHNBx 2014.14.37.2]. 13-16, Paratype 2, SL = 17 mm [UB-84-2-13]. 9-12, Modulus modulus (LinNAEUS, 1758), Madibenthos Expedition (Martinique, Gros Îlet, Stn AD618 1m, 14 ${ }^{\circ} 32.9^{\prime} \mathrm{N}-61^{\circ} 01.3^{\prime} \mathrm{W}$ ). SL= 8.5 mm [MNHN-IM2018-10782]. 

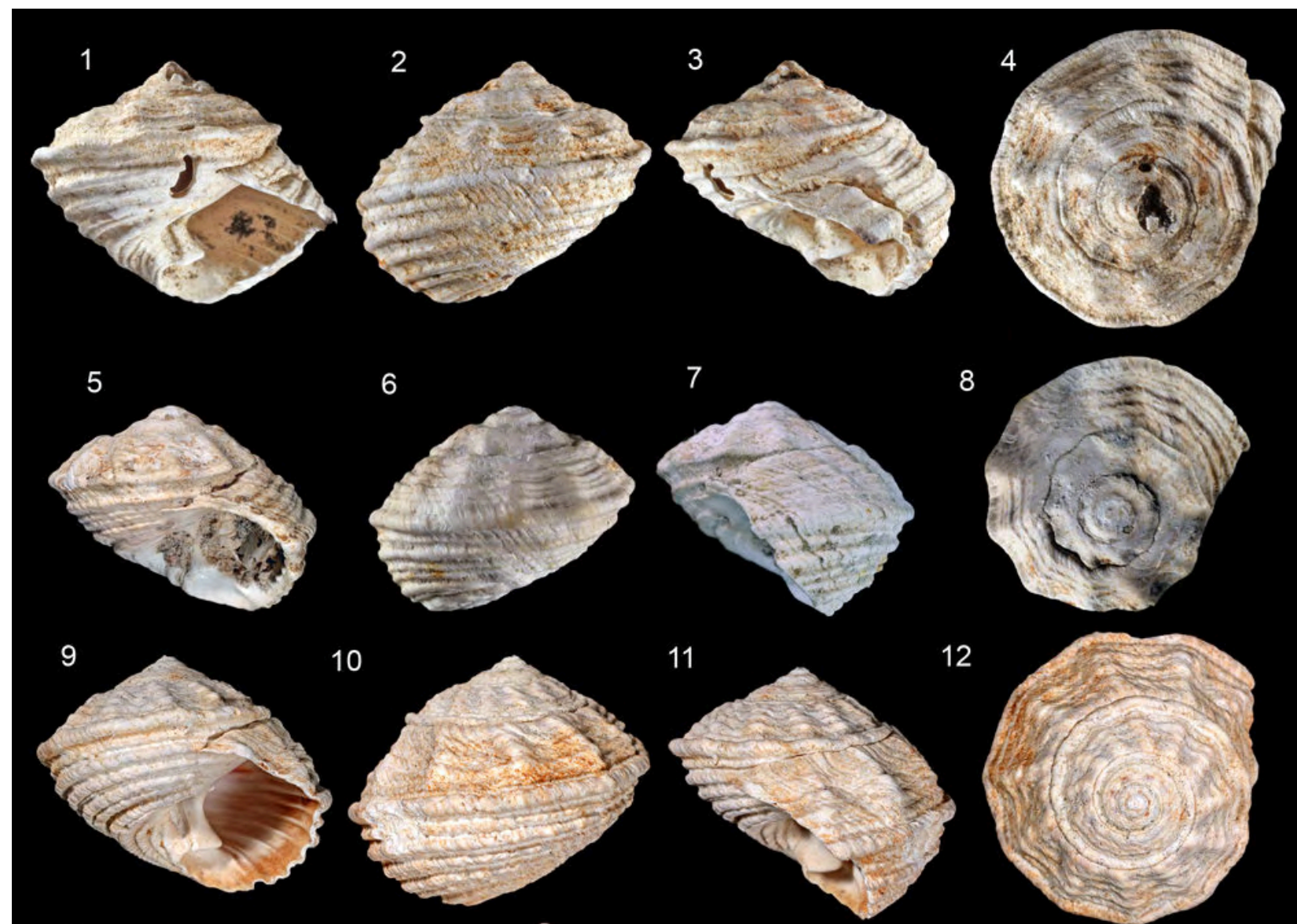

12
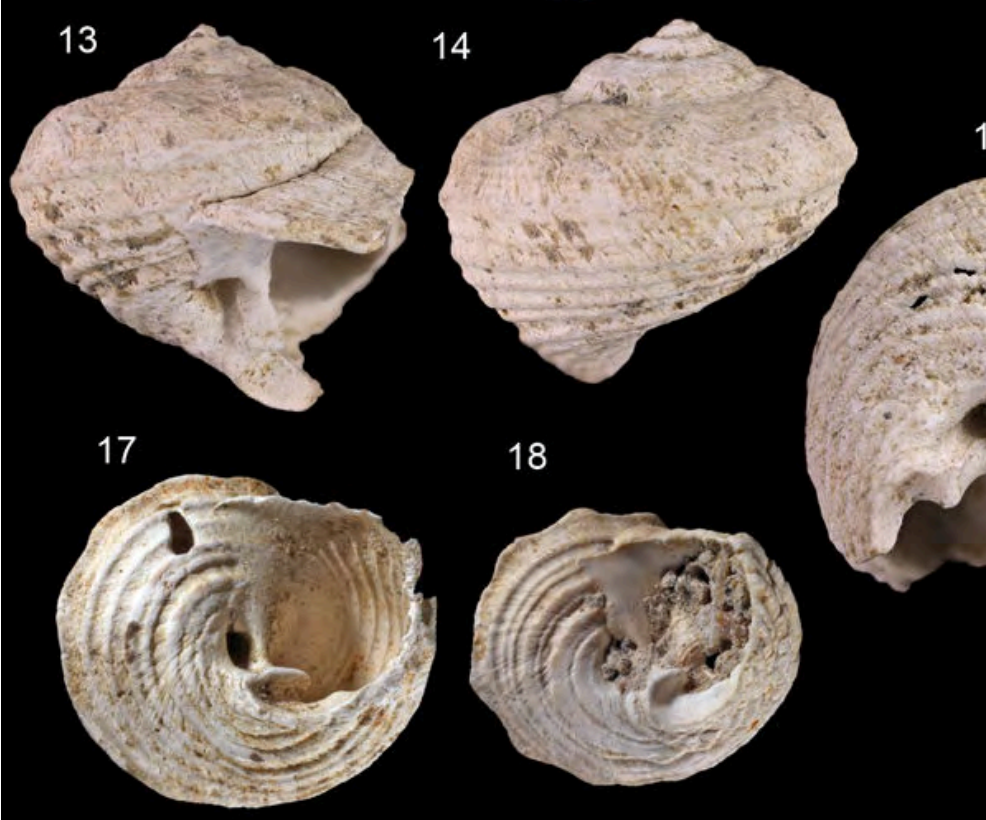

18

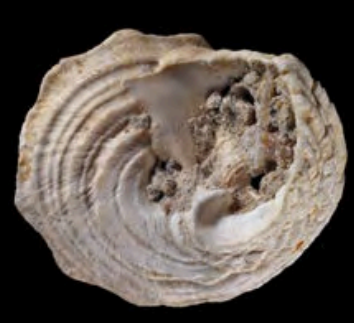


Plate 2: 1-10. Trochomodulus sublaevigatus (ORBIGNY, 1852). Upper Oligocene (Chattian), Landes. 1-3 St-Paul-lèsDax (Lestrilles), SL= $10 \mathrm{~mm}$ [MNHN.F.A71170]; 4-6, St-Paul-lès-Dax, lectotype designated (SL=16.2 mm) coll. Grateloup [UB-65-2-141]; 7-10, St-Paul-lès-Dax (Abesse "Château"), SL= 10 mm [MNHN.F.71171]. 11-19. Trochomodulus stampinicus sp. nov. Lower Oligocene (Rupelian), Landes. 11-16, Orist, 11-13, paratype 2 SL= 9 $\mathrm{mm}$ [MNHN.F.71172]; 14-16, Orist, paratype $1 \mathrm{SL}=2.4 \mathrm{~mm}$ [MNHN.F.71173]; 17-19, holotype SL= $15.5 \mathrm{~mm}$ [MNHN.F.71174], Gaas (Lagouarde). 
Carnets Geol. 20 (7)

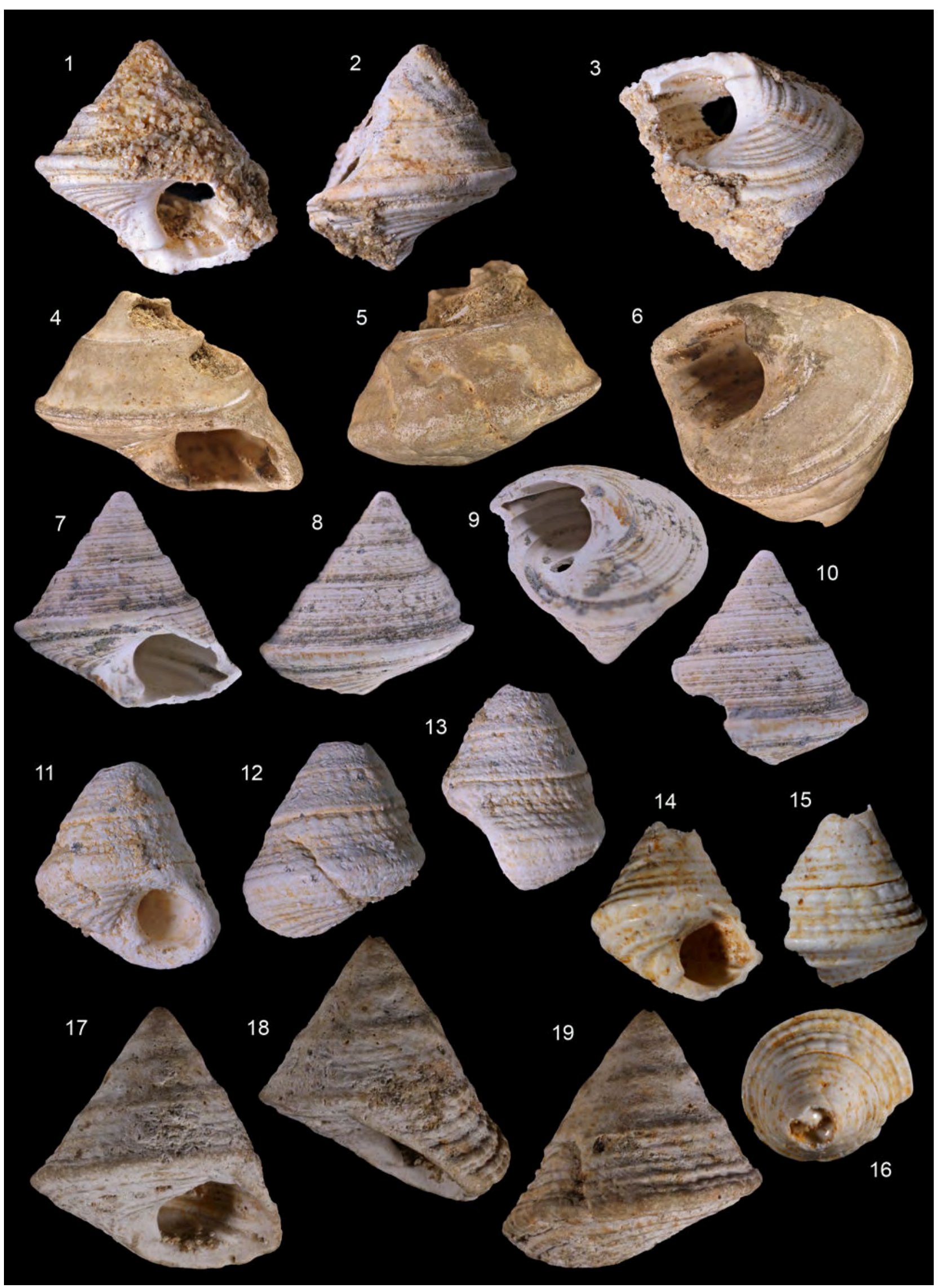

137 
Plate 3: 1-4. Modulus? basteroti BenoIST, 1874. Lower Miocene (Aquitanian), Aquitaine Basin, Gironde, Saucats (Lariey), SL= $12 \mathrm{~mm}$, coll. FAULLUMmeL [MNHN.F.A71169]. 5-9. Incisilabium parisiensis (DeSHAYES, 1832), Middle Eocene (Bartonian), Paris Basin, Oise, Saint-Vaast-lès-Mello "Barisseuse", SL= 18 mm, coll. PACAUD [MNHN.F.A51573]. 10-18. Incisilabium trochiformis sp. nov. Upper Eocene (Priabonian), Landes, Peyrehorade "Lasserre". 10-12, SL= $5.1 \mathrm{~mm}$, holotype [MNHN.F.A71175]; 13-14, SL= $4.4 \mathrm{~mm}$, paratype [MNHN.F.A71176]; 15-16, SL= $3.7 \mathrm{~mm}$, paratype [MNHN.F.A71177]. 17-18, paratype [MNHN.F.A71178]. 


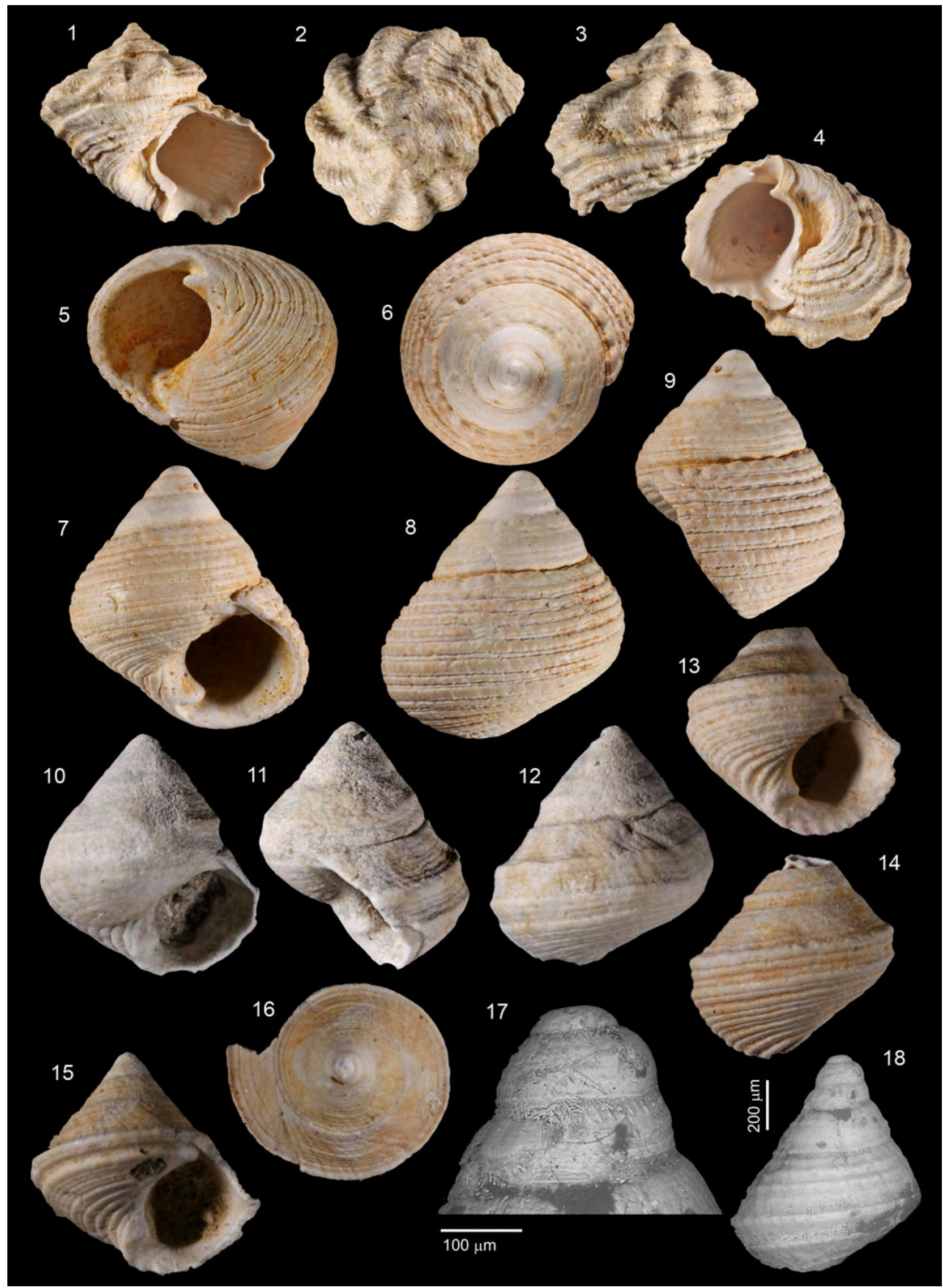




\section{Nomenclatural note:}

Life Sciences Identifier (LSID)

http://zoobank.org/References/030E377D-4F46-42B0-A6B4-C0E121519455

- Modulus benoisti Lozouet, Cahuzac \& Charles, 2020

http://zoobank.org/NomenclaturalActs/73348547-e1e5-433c-8d38-35d58012d4d1

- Trochomodulus stampinicus Lozouet, CAHUZAC \& CHARLES, 2020

http://zoobank.org/NomenclaturalActs/6cc3cc64-fe9a-4b90-b8b0-4e0e28b84fb0

- Incisilabium trochiformis LOZOUET, CAHUZAC \& CHARLES, 2020

http://zoobank.org/NomenclaturalActs/5E0CFEF6-C0EE-4FD3-A3C6-5DBFDE7C8FF5 